\title{
Novel ophiostomatalean fungi from galleries of Cyrtogenius africus (Scolytinae) infesting dying Euphorbia ingens
}

Johannes Alwyn van der Linde ${ }^{\mathrm{a}}$, Diana L. Six ${ }^{\mathrm{b}}$, Wilhelm Z. De Beer ${ }^{\mathrm{a}}$, Michael J. Wingfield ${ }^{\mathrm{a}}$, Jolanda Roux ${ }^{\mathrm{a}}$

${ }^{\text {a }}$ Department of Microbiology and Plant Pathology, Forestry and Agricultural Biotechnology Institute (FABI), University of Pretoria, Pretoria 0002, South Africa

${ }^{\mathrm{b}}$ College of Forestry and Conservation, Department of Ecosystem and Conservation Sciences, The University of Montana, Missoula, Montana 59812, United States of America

Corresponding author:

jolanda.roux@fabi.up.ac.za

Telephone: +27 (12) 420-3938

Fax: +27 (12) 420-3960

\begin{abstract}
Euphorbia ingens trees have been dying in large numbers in the Limpopo Province of South Africa for approximately 15 years. The ambrosia beetle Cyrtogenius africus is often found infesting diseased and dying trees. The aim of this study was to identify the ophiostomatoid fungi occurring in the galleries of C. africus. Logs infested with this beetle were collected from the KwaZulu-Natal, Limpopo, Mpumalanga, and North West Provinces of South Africa. Fungi belonging to the Ophiostomatales were identified based on morphology and comparison of sequence data for the $\beta$-tubulin, ITS1-5.8S-ITS2 and LSU gene regions. A novel species of Ophiostoma and a novel genus in the Ophiostomatales were identified. Inoculation studies with these fungi produced lesions in the branches of healthy E. ingens trees.
\end{abstract}


Keywords: Ophiostoma, Ophiostomataceae, ophiostomatalean fungi, Ophiostomatales, Scolytinae

\section{Acknowledgements}

We thank the Department of Science and Technology (DST), National Research Foundation (NRF) and DST/NRF Centre of Excellence in Tree Health Biotechnology (CTHB), for financial support; Dr. Hugh Glen for assistance with Latin names and Dr. Roger Beaver for assistance with beetle identification. Mr. Gert van der Merwe, Mr. Thomas Ndala, Mr. Henk Fourie and Buyskop Game Farm are thanked for permission to use their properties for field studies.

\section{Introduction}

The ophiostomatoid fungi were originally classified, based on morphology, as a group of fungi with similar sexual structures that had evolved in close association with insects (Wingfield et al. 1993, De Beer et al. 2013). These structures include flask-shaped ascomata with long necks raised above the substrate and exuding sticky spore drops (containing ascospores) that aid in dispersal via insects (Dowding 1984, Malloch and Blackwell 1993). Three ascomycete genera, Ceratocystis, Ceratocystiopsis, and Ophiostoma, were originally included in the group referred to as ophiostomatoid fungi (Wingfield et al. 1993). Phylogenetic inference based on DNA-sequence analyses later revealed that the ophiostomatoid fungi represent a polyphyletic assemblage, comprising two distinct orders, the Ophiostomatales and the Microascales (Hausner et al. 1993, Spatafora and Blackwell 1994, Zipfel et al. 2006). The Ophiostomatales contains only one family (Ophiostomataceae) with six genera, Ceratocystiopsis, Fragosphaeria, Leptographium sensu lato, Ophiostoma sensu lato, Raffaelea sensu stricto and Graphilbum (De Beer et al. 2013), while the Microascales is comprised of five families, two of which, the Ceratocystidaceae and Graphiaceae, accommodate the ophiostomatoid genera (Réblová et al. 2011, De Beer et al. 2013, De Beer et al. 2014). 
Ophiostomatalean fungi have various ecological associations with ambrosia and bark beetles (Paine et al. 1997, Harrington 2005). While bark beetles feed in the phloem and sometimes have dependent associations on the fungi they vector, ambrosia beetles bore into the xylem of host trees where they are completely dependent upon their fungal associates for food (Beaver 1989, Hulcr and Dunn 2011, Six 2012). Ambrosia beetles are known to infest dead or severely stressed trees (Batra 1967, Wood 1982). However, studies have shown that increasing numbers of these beetles, together with their fungal partners, can infest and kill healthy trees leading to substantial tree mortality (Hulcr and Dunn 2011, Ploetz et al. 2013, Ranger et al. 2015). For example, in Japan increasing levels of oak die-back caused by Platypus quercivorus Murayama and its fungal symbiont Raffaelea quercivora Kubono \& Shin. Ito, have been reported (Kamata et al. 2002, Kubono and Ito 2002). Likewise, in the United States of America (USA) laurel wilt disease is caused by Raffaelea lauricola T.C. Harr., Fraedrich \& Aghayeva that is vectored by the invasive ambrosia beetle Xyloborus glabratus Eichhoff (Fraedrich et al. 2008, Harrington et al. 2008).

Euphorbia ingens E. Meyer: Boissier trees, native in the savanna landscape of South Africa, have been dying in large numbers for several years (Roux et al. 2008, 2009, Van der Linde et al. 2011a,b). The first reports of die-offs were from the Limpopo Province of South Africa (RSA) and were associated with various biotic factors (Malan 2006, Roux et al. 2008, 2009). Pilot studies showed the presence of several ophiostomatalean fungi in the tunnels of beetles infesting dying E. ingens (Roux et al. 2008, 2009). Two weevils [Cossonus sp. Claireville and Stenoscelis sp. Wollaston (Cossoninae)] as well as the ambrosia beetle Cyrtogenius africus Wood (Scolytinae) were identified from diseased and dying E. ingens trees (Van der Linde et al. 2011a,b). Van der Linde et al. (2011b), however, identified only a single species of ophiostomatalean fungi, Knoxdaviesia serotectus (J.A. van der Linde \& Jol. Roux) Z.W. de Beer \& M.J. Wingf. (Ceratocystidaceae), from the secondary phloem of dying trees associated with a Cossonus species. 
The aim of this study was to identify ophiostomatalean fungi collected in the tunnels of C. africus on E. ingens in all provinces of South Africa where the tree occurs. Ophiostomatalean fungi were identified using sequence data of multiple gene regions and their potential role in tree die-offs was considered using artificial inoculation studies to assess pathogenicity to the host tree.

\section{Materials and Methods}

\section{Collection of samples and isolations}

Sections of E. ingens stems were cut from trees showing signs of beetle infestation at six sites in South Africa over a period of three years (2012-2014), from early autumn (March) to early spring (August) during each year. One log was sampled from each of 10 trees at each site. The sites were located in KwaZulu-Natal (Eshowe - March 2013, Coordinates: 2848'42.64"S 31³0'30.10"E), Limpopo (Bela-Bela - August 2012/July 2013, 2451'48.30"S 28²0'5.90"E; Last Post - June 2014, 23²17'21.39"S 2955'27.93"E), Mpumalanga (Lydenburg - July 2012, $24^{\circ} 55^{\prime} 53.87^{\prime \prime S} 30^{\circ} 19^{\prime} 7.09^{\prime \prime E}$ ) and North West Provinces (Brits - July 2013, 2542'59.27"S $27^{\circ} 42^{\prime} 9.24^{\prime \prime E}$; Enzelsberg - July 2013, 2522'58.05"S 26º 16'4.21"E).

Logs were carefully dissected in the laboratory to expose galleries of C. africus. Isolations were made directly from fungal structures, typical of ophiostomatalean fungi, in the galleries of $C$. africus as well as from stained tissue surrounding the galleries. Spore drops from ascomata were placed, using a sterilised needle, on $2 \%$ MEA (MEA; $15 \mathrm{~g}$ agar and $20 \mathrm{~g}$ malt extract $\mathrm{l}^{-1}$ ) containing $0.4 \mathrm{~g}$ streptomycin sulphate $\mathrm{l}^{-1}$. MEA plates were incubated at $25^{\circ} \mathrm{C}$ for up to five days and single hyphal tips from germinating spores transferred to fresh MEA plates. Isolates were deposited in the Culture Collection (CMW) of the Forestry and Agricultural Biotechnology Institute (FABI), University of Pretoria, Pretoria, South Africa, and representative isolates were deposited in the Centraalbureau voor Schimmelcultures (CBS), 
Utrecht, The Netherlands. Herbarium specimens representing novel species were deposited with the National Fungal Collection (PREM), Pretoria, South Africa.

\section{Fungal Morphology and Growth}

Fruiting structures of the ophiostomatalean fungi, obtained from both plant material and MEA plates, were examined by mounting structures in distilled water on glass microscope slides and examining these using a Zeiss microscope. Images of relevant, representative structures were captured with an Axiocam digital camera (Axiovision 3.1). Informative characteristics for the ophiostomatalean fungi were measured (50 measurements each) and presented as (min-) avg. \pm std. dev. (-max) for the length and width of the structures $(1 / \mathrm{w})$.

Optimal temperatures for growth of the fungi were determined by placing $5 \mathrm{~mm}$ agar discs, obtained from five-day-old cultures, with the mycelium facing down, at the centers of 90 mm MEA plates. Five replicates were used for each isolate at each temperature. Plates were incubated at temperatures ranging from $10{ }^{\circ} \mathrm{C}$ to $35^{\circ} \mathrm{C}$ at $5{ }^{\circ} \mathrm{C}$ intervals. Incubation was conducted in the dark for 10 days with measurements taken every 24 hours. Two measurements of the total diameter were made perpendicular to one another. Averages of the diameters were calculated and one-way analysis of variance (ANOVA) was conducted $(\mathrm{P}<0.05$ as significant, JMP 12.0.1 SAS Institute 2015) to determine at which temperature each of the species grew best. Data were tested for normality (Shapiro-Wilk’s W, Shapiro and Wilk 1965) with nonnormal data transformed ( $\ln +1$; to account for zeros in the data) and analysed using a KruskalWallis one way ANOVA.

\section{DNA extraction, PCR, Sequencing and Phylogenetic analyses}

DNA was extracted from the mycelium of five-day-old isolates (with ophiostomatalean culture morphology) using PrepMan® Ultra (Applied Biosystems, Foster City, USA). DNA concentrations were determined using a Nanodrop ND-1000 Spectrophotometer (Thermo-Fisher Scientific, Wilmington, USA). The polymerase chain reaction (PCR), using an Applied 
Biosystems Veriti thermocycler, was used to amplify the $\beta$-tubulin (BT) gene region using the primers T10 (O’Donnell and Cigelnik 1997) or Bt2A together with Bt2B (Glass and Donaldson 1995), the internal transcribed spacer (ITS) regions 1 and 2 including the 5.8S gene using the primers ITS1 and ITS4 (White et al. 1990), and the ribosomal large subunit (LSU) gene region using the primers LR5 and LROR (Vilgalys and Hester 1990). PCRs were conducted using the protocol described by Van der Linde et al. (2011b). PCR products were confirmed using an agarose gel (2 \%; Whitehead Scientific, Cape Town, South Africa) loaded with GelRed (Anatech, USA), visualised under UV illumination. A 100 bp DNA molecular marker (O’RangeRuler'TM 100 bp DNA ladder, Fermentas Life Sciences, Vilnius, Lithuania) was used to estimate the sizes of the PCR products. Amplification products were purified using DNA Clean \& Concentrator ${ }^{\mathrm{TM}}-5$ (ZYMO Research, Irvine, USA).

Purified PCR products were sequenced using an ABI 3700 DNA analyser (Applied Biosystems) following the instructions provided by the manufacturer. Mega 5.0 (Tamura et al. 2007) was used to construct contigs based on forward and reverse sequences. Sequences were submitted to searches in the BLASTn database to establish closest matches. Sequences of the most closely related fungi for all three gene regions were downloaded from Genbank and included in phylogenetic analyses. Sequences obtained from this study and Genbank were aligned using MAFFT 5.851 (Katoh et al. 2002).

Aligned sequences were analyzed with Maximum Parsimony (heuristic searches, with random stepwise addition and tree bisection as branch swapping algorithms) in PAUP* 4.0b10 (Swofford 2002). Bootstrap analyses, with 1000 replicates (Felsenstein 1985), were determined for all datasets. Posterior probabilities were determined using Bayesian inference (MrBayes 3.1.2, Huelsenbeck and Ronquist 2001) using the Monte Carlo Markov chain (MCMC) method (parameters set at four chains producing 5,000,000 generations, recording trees every 100 generations). The appropriate nucleotide substitution model was determined using jModelTest 
0.1.1 (Posada 2008) with burn-in values determined using graphical analysis (Tracer 1.5) at the point where values converged.

\section{Pathogenicity study}

Three isolates of each of the fungi identified in this study were selected for pathogenicity trials conducted on E. ingens trees growing under field conditions at Bela-Bela (245ㄴ $\left.48.30^{\prime \prime} S 28^{\circ} 20^{\prime} 5.90 " E\right)$ in the Limpopo Province. Sterilized wooden tooth picks were autoclaved in malt extract broth and placed onto the surfaces of $2 \%$ MEA plates. These plates were left for three days to ensure sterility before inoculation with the test fungi (Van der Linde et al. 2011b). Five plates were prepared for each of the isolates as well as the control and grown for five days prior to inoculation. The control consisted of sterile toothpicks on the surface of MEA that had not been inoculated with fungi. Toothpicks for each isolate (seven in total), including the control, were inserted into five separate branches on seven trees. Toothpicks were inserted to a depth of $3 \mathrm{~mm}$ in secondary tier healthy succulent branches. Branches ranged between 25 and $30 \mathrm{~cm}$ in circumference.

Six weeks after inoculation, all inoculated branches were removed for evaluation. External lesions extending from the entry point of the toothpicks were measured (parallel with branch length). The depth and width of internal rotting was also measured after cutting open the branches at the point of inoculation. Isolations were made from any visible lesions to confirm fungal identity and to comply with Koch's postulates. The entire experiment was repeated once. Data from both experiments were analysed separately and then combined for each isolate to determine variation in external lesion length and internal rotting (depth and width). The mean of the external lesion length and area of internal rotting (depth and width) was compared among all the isolates tested using one-way analysis of variance (ANOVA) with $\mathrm{P}<0.05$ set as significant (JMP 12.0.1 SAS Institute 2015). Normality of data was tested with Shapiro-Wilk's W with non-normal data transformed ( $\ln +1$; to account for zeros in the data) and analysed with a Kruskal-Wallis one way ANOVA. No variance was found with the control (replicates showed 
zero lesion length) and consequently, each isolate was compared against zero using independent, one sided t-tests, Bonferroni-corrected for multiple comparisons ( $\alpha=0.05$, JMP 12.0.1).

\section{Results}

\section{Fungi isolated}

Cyrtogenius africus was obtained from logs at all sites. Fifty-five isolates resembling species of ophiostomatalean fungi were obtained from beetle galleries and surrounding stained tissues from 40 of the 60 logs. Of the 55 isolates obtained in this study two different species were identified. Thirty-nine of the isolates belonged to one species, with 13 directly isolated from sporocarps in C. africus tunnels and 26 obtained from fungal stain surrounding the tunnels. Of the 39 isolates four were obtained from Bela-Bela (three trees), four from Brits (four trees), three from Eshowe (three trees), six from Enzlesberg (six trees), 15 from Last Post (10 trees) and seven from Lydenburg (seven trees). Sixteen of the 55 isolates were identified as another species with six obtained directly from sporocarps in C. africus tunnels and 10 obtained from fungal stain surrounding the tunnels. All sixteen isolates of the second species were obtained from Bela-Bela (7 trees), with none from the other sites investigated. The two fungal species identified were not found in the same $C$. africus tunnels in Bela-Bela.

\section{Fungal Morphology and Growth}

Sexual and asexual structures were observed in the galleries of $C$. africus, with the two states not observed to occur within the same tunnels. The one state was characterized by ascomata with spore droplets and the other state had hyaline sporothrix-like conidiophores in the tunnels. All cultures obtained were white with two distinct culture morphologies; one with radiate-to chrysanthemum-like (in reference to the flower morphology of this plant genus, usually used to describe Phytophthora and Pythium culture morphology, Mrázková et al. 2011) 
Table 1 Locality and Genbank accession numbers of representative isolates sequenced and used in phylogenetic analyses

\begin{tabular}{|c|c|c|c|c|c|c|c|}
\hline Species & CMW no. ${ }^{a}$ & CBS no. $^{\mathrm{b}}$ & PREM no. ${ }^{c}$ & Locality & ITS & LSU & $\beta$-tubulin \\
\hline Ophiostoma thermarum & $38929^{\mathrm{d}}$ & 140081 & 61239 & Bela-Bela & KR051114 & KR051126 & KR51102 \\
\hline O. thermarum & $38930^{\mathrm{d}, \mathrm{e}}$ & 139747 & 61238 & Bela-Bela & KR051115 & KR051127 & KR51103 \\
\hline O. thermarum & 38931 & - & - & Bela-Bela & KR051116 & KR051128 & KR51104 \\
\hline O. thermarum & 38932 & - & - & Bela-Bela & KR051117 & KR051129 & KR51105 \\
\hline O. thermarum & $38940^{\mathrm{d}}$ & 140082 & 61240 & Bela-Bela & KR051118 & KR051130 & KR51106 \\
\hline Aureovirgo volantis & $41238^{\mathrm{d}, \mathrm{e}}$ & 139648 & 61235 & Last Post & KR051119 & KR051131 & KR51107 \\
\hline A. volantis & $41250^{\mathrm{d}}$ & 139649 & 61236 & Last Post & KR051120 & KR051132 & KR51108 \\
\hline A. volantis & 42282 & - & - & Eshowe & KR051123 & KR051133 & KR51109 \\
\hline A. volantis & 42285 & - & - & Lydenburg & KR051121 & KR051134 & KR51110 \\
\hline A. volantis & 42287 & - & - & Bela-Bela & KR051124 & KR051135 & KR51111 \\
\hline A. volantis & 42290 & - & - & Enzelsberg & KR051122 & KR051136 & KR51112 \\
\hline A. volantis & $42292^{\mathrm{d}}$ & 139645 & 61237 & Brits & KR051125 & KR051137 & KR51113 \\
\hline
\end{tabular}

${ }^{\text {a }}$ CMW, Culture Collection of the Forestry and Agricultural Biotechnology Institute (FABI), South Africa

${ }^{\mathrm{b}} \mathrm{CBS}$, Centraalbureau voor Schimmelcultures, Netherlands

${ }^{\mathrm{c}}$ PREM, South African National Collection of Fungi, South Africa

${ }^{\mathrm{d}}$ Isolates used in pathogenicity and growth study

e Type strains 
aerial mycelial growth, with the other culture morphology type having no aerial mycelia and an inconspicuous, near translucent, shiny appearance.

The six isolates (three each of the two species, Table 1) selected for further study had significant differences in growth rates at the different temperatures. The optimal growth rate was $30{ }^{\circ} \mathrm{C}$ for species 1 (F statistic: $327.906, \mathrm{df}=5, \mathrm{P}<0.001$ ) and species 2 (F statistic: 1394.727, $\mathrm{df}=5, \mathrm{P}<0.001)$. The temperature range supporting growth was similar for both species.

\section{DNA sequence analyses}

Analyses of the ITS data $(\mathrm{TL}=717, \mathrm{CI}=0.517, \mathrm{RI}=0.856,45.7 \%$ of characters parsimony informative, TreeBase: TB17782) (Fig. 1) revealed that the isolates obtained from $E$. ingens in the present study formed two groups, representing taxa distinct from all known species in the Ophiostomatales. The first taxon was most closely related to Ophiostoma bragantinum, and grouped peripheral to the S. schenckii-O. stenoceras complex within Ophiostoma sensu lato. The second taxon grouped with a lineage closest to, but clearly distinct from the Sporothrix lignivora complex and the genus Graphilbum. The two taxa exhibited similar relationships with other ophiostomatalean lineages in the LSU tree $(\mathrm{TL}=283, \mathrm{CI}=0.525, \mathrm{RI}=0.832,24.8 \%$ of characters parsimony informative, TreeBase: TB17783) (Fig. 2). The ITS and LSU datasets were supported by high bootstrap values as well as posterior probabilities obtained from Bayesian analysis (ITS model: GTR+G, LSU model: TIM3+I+G, burn-in values for both datasets were 3000). BT sequences are not available for all taxa included in the ITS and LSU trees and so a similar tree comparison could not be made for these gene sequences. However, based on BLAST searches (data not shown) the sequences for both taxa were distinct from all available BT sequences for the Ophiostomatales. 
Fig. 1. The most parsimonious tree obtained from maximum parsimony analyses of ITS1-5.8S-ITS2 sequence data. Nodes in bold indicate MCMC posterior probabilities values $\geq 0.95$ and values at the nodes are mean parsimony bootstrap values. $T$ indicates ex-type strains

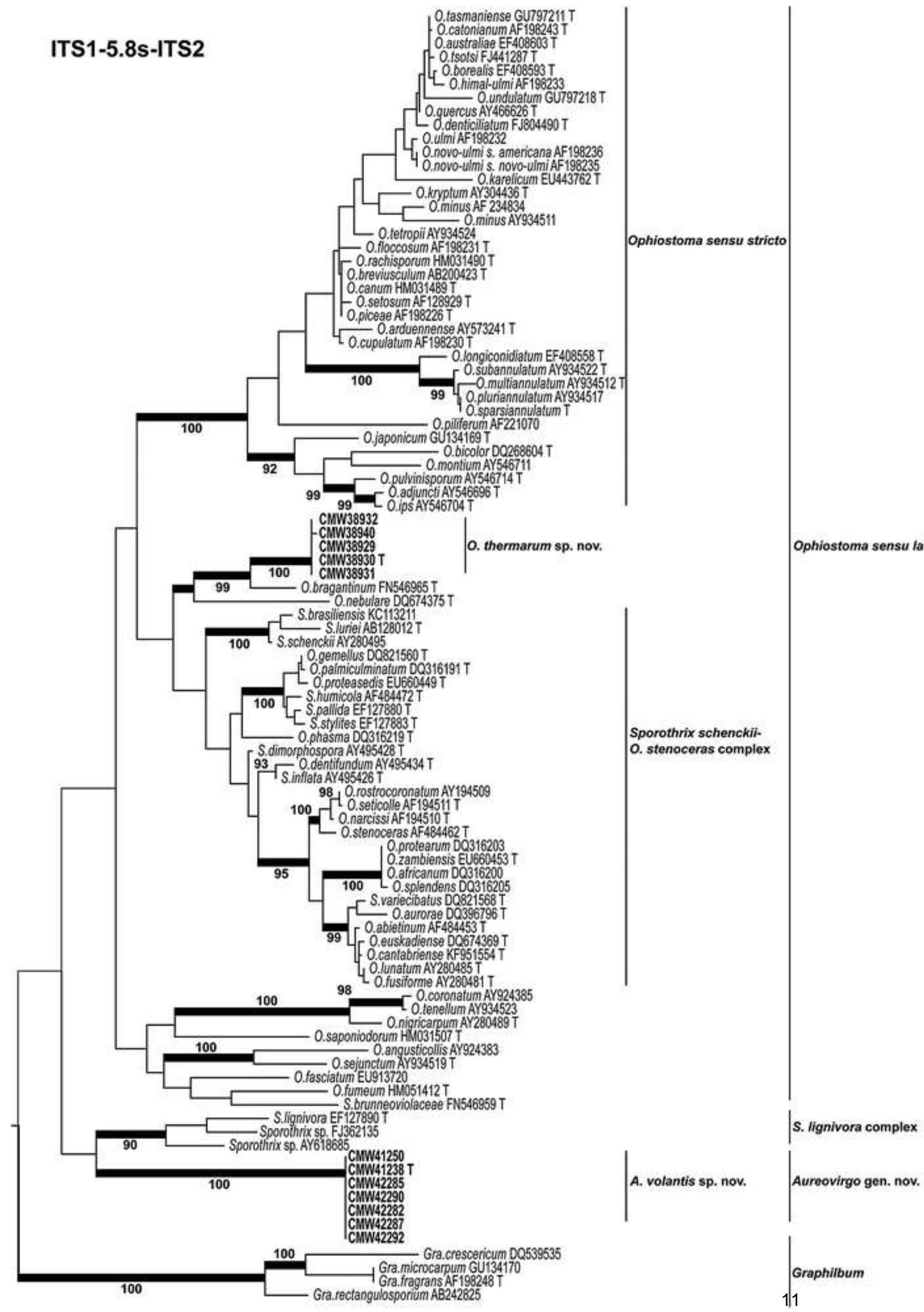


Fig. 2. The most parsimonious tree obtained from maximum parsimony analyses of LSU sequence data. Nodes in bold indicate MCMC posterior probabilities values $\geq 0.95$ and values at the nodes are mean parsimony bootstrap values. $T$ indicates ex-type strains

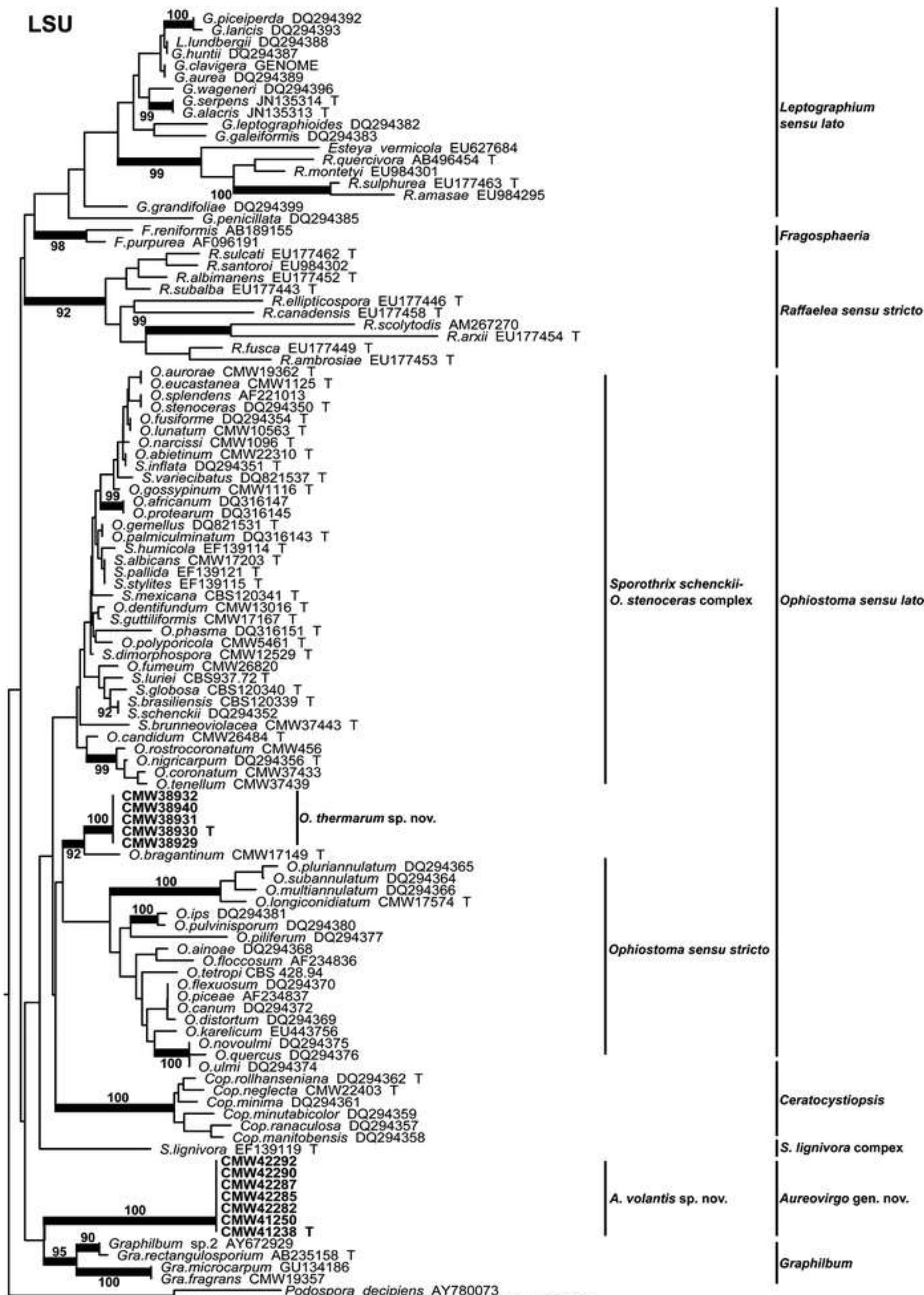




\section{Taxonomy}

Analyses of DNA sequences of the ITS, LSU and BT gene regions of isolates obtained in this study confirmed that these isolates represented two novel taxa distinct from previously described species. One of these clearly represents a new genus in the Ophiostomatales, while the other fungus is described as a new species of Ophiostoma sensu lato.

Aureovirgo J.A. van der Linde, Z.W. de Beer \& Jol. Roux gen. nov.

Mycobank MB813870

Etymology: Genus name refers to the golden appearance of the immature ascomata and the pure white color of the cultures ("Aureovirgo" refers to a golden maiden with an unstated overtone of virginal whiteness).

Type species: Aureovirgo volantis J.A. van der Linde, Z.W. de Beer \& Jol. Roux

Ascomatal bases honey colored (19") when immature to fuscous (13""k) when mature, necks dark, ostiolar hyphae hyaline, ascospores allantoid with ellipsoidal sheaths. Leptographium-like asexual state: Conidiophores mononematous, hyaline, stipe cylindrical and simple. Conidia oblong-elliptical and oval ovate.

Aureovirgo volantis J.A. van der Linde, Z.W. de Beer \& Jol. Roux sp. nov. (Fig. 3)

Mycobank MB813872

Etymology: the species name is derived from the Latin word "volanti" for flying. This describes the distribution of the fungus with the insect $C$. africus.

Mycelium on MEA produces pure white radiate to chrysanthemum aerial growth. Sexual state found only in insect galleries, not observed in culture. Ascomatal bases honey coloured (19") when immature, to fuscous (13"'k) when mature (77.5-) $78.7-94.9(-97.3) \mathrm{x}$ (90.61-) 92.1 - 106.9 (-110.6) $\mu \mathrm{m}(86.8$ x $99.5 \mu \mathrm{m}, 1 / \mathrm{w}$ 0.9), necks dark brown (164.5-) 202.2 

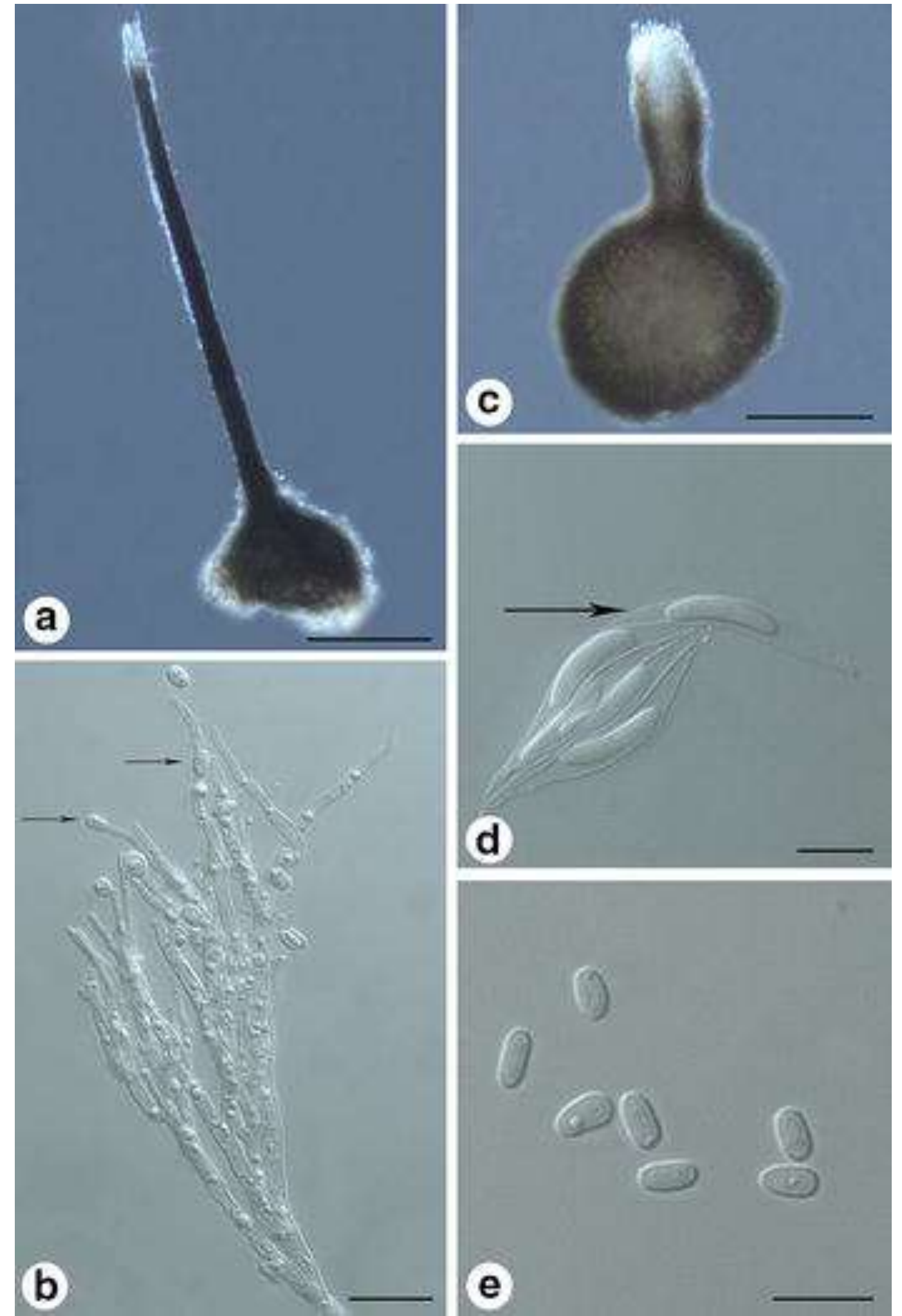

Fig. 3. Aureovirgo volantis (CMW41238). a Mature ascocarp with ostiolar hyphae.

b Leptographium-like conidiophore with conidiogenous cells (arrows indicate conidiogenous cells). c Immature ascocarp with typical honey coloured base. $\mathbf{d}$ Allantoid ascospores with ellipsoidal sheath (arrows indicate ellipsoidal sheath). e Oblong-elliptical and oval ovate conidia. Scale bars $\mathbf{a}, \mathbf{c}=100 \mu \mathrm{m}, \mathbf{b}=10 \mu \mathrm{m}, \mathbf{d}, \mathbf{e}=5 \mu \mathrm{m}$ 
- 345.2 (-359.3) x (16.0-) $15.9-21.3(-23.9) \mu \mathrm{m}(273.7$ x $18.6 \mu \mathrm{m}, 1 / \mathrm{w} 14.7)$, ostiolar hyphae hyaline (33.6-) $34.1-67.1(-72.9) \times(3.6-) 3.7-4.5(-4.6) \mu \mathrm{m}(50.6$ x $4.1 \mu \mathrm{m}, 1 / \mathrm{w} 12.3)$, ascospores allantoid with ellipsoidal sheaths (6.9-) $7.2-8.0(-8.3) \times(1.5-) 1.7-2.1(-2.2) \mu \mathrm{m}$ (7.6 x $1.9 \mu \mathrm{m}, 1 / \mathrm{w} 4.0)$. Asexual state leptographium-like. Conidiophores mononematous, hyaline (22.4-) $25.2-46.4(-52.0) \times(1.0-) 0.9-1.7(-1.9) \mu \mathrm{m}(35.8 \times 1.3 \mu \mathrm{m}, 1 / \mathrm{w} 27.5)$, conidia oblong-elliptical and oval ovate (3.5-) $3.7-4.8(-5.9) \times(1.6-) 1.9-2.9(-3.8) \mu \mathrm{m}(4.3$ x $2.4 \mu \mathrm{m}, 1 / \mathrm{w} 1.8$ ). Optimum temperature for growth temperature $30^{\circ} \mathrm{C}$, growing at 9.7 $\mathrm{mm} /$ day, with minimum growth at $15{ }^{\circ} \mathrm{C}$ and maximum growth at $35^{\circ} \mathrm{C}$.

HOLOTYPE. SOUTH AFRICA, LIMPOPO PROVINCE: Last Post, isolated directly from Cyrtogenius africus galleries on diseased Euphorbia ingens trees, June 2014, Van der Linde JA, holotype PREM 61236 dry culture on MEA, ex-holotype culture CMW41238 = CBS139648; paratype PREM 61236, ex-paratype culture CMW41250 = CBS139649. Ascomata not observed in culture.

Additional specimens examined: Limpopo Province (Bela-Bela; July 2013, Van der Linde JA; CMW42287), KwaZulu-Natal (Eshowe; March 2013, Van der Linde JA; CMW42282), Mpumalanga (Lydenburg; July 2012, Van der Linde JA; CMW42285), North West (Brits; July 2013, Van der Linde JA; CMW42292 = CBS139645 and Enzelsberg; July 2013 Van der Linde JA; CMW42290) isolated from C. africus galleries on diseased E. ingens trees.

Ophiostoma thermarum J.A. van der Linde, Z.W. de Beer \& Jol. Roux sp. nov. (Fig. 4)

Mycobank MB813873 

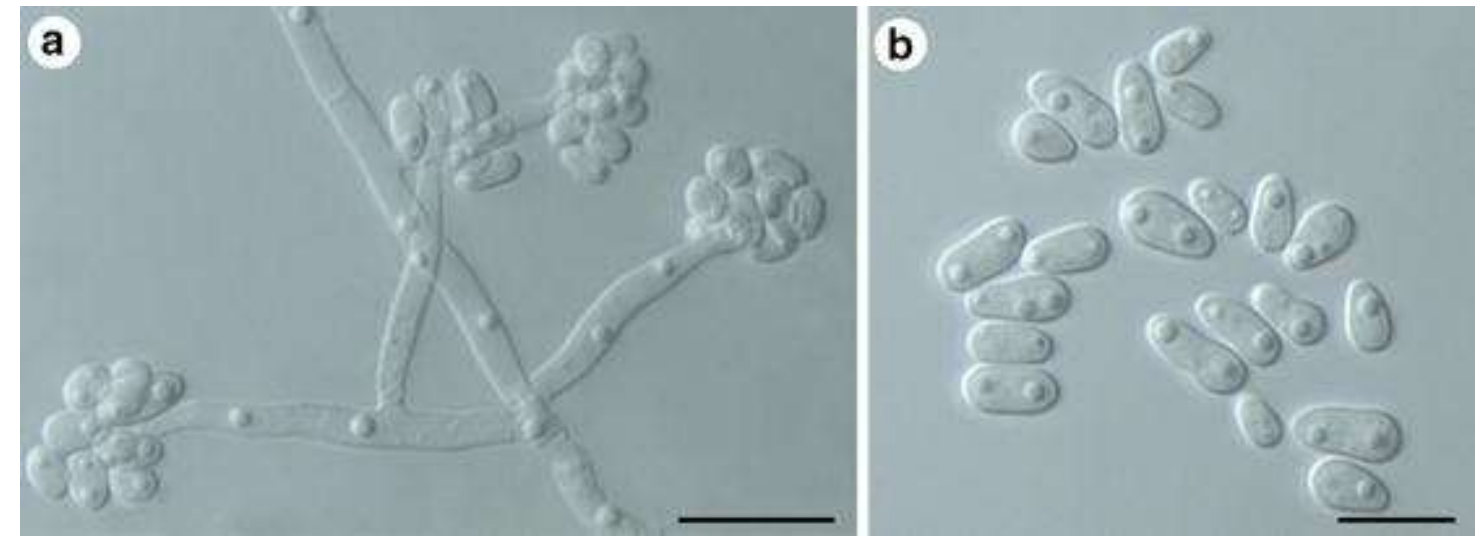

Fig. 4. Ophiostoma thermarum (CMW38930). a Sporothrix-like condiophore with conidiogenous cells. b Oblong-elliptical and obovate conidia. Scale bars $\mathbf{a}=10 \mu \mathrm{m}$, $\mathbf{b}=5 \mu \mathrm{m}$

Etymology: The species name refers to the locality from where this species was collected, BelaBela, which is surrounded by geothermal springs ("thermarum" meaning place of warm baths).

Growth on MEA barely visible, shiny white yeast-like growth with no aerial mycelium. Sexual state not observed on plant material or culture. Asexual state sporothrix-like.

Conidiophores (56.0-) $62.3-101.3(-107.4) \times(1.00-) 1.1-2.1(-2.4) \mu \mathrm{m}(81.8 \times 1.6 \mu \mathrm{m}, 1 / \mathrm{w}$ 51.1), conidia oblong-elliptical and obovate (4.1-) $4.4-5.6(-6.5) \times(1.4-) 2.0-2.8(-3.3) \mu \mathrm{m}$ (5.0 x $2.4 \mu \mathrm{m}, 1 / \mathrm{w} 2.1)$. Optimum temperature for growth $30^{\circ} \mathrm{C}$, growing at $9.4 \mathrm{~mm} / \mathrm{day}$, with minimum growth at $15{ }^{\circ} \mathrm{C}$ and maximum growth at $35^{\circ} \mathrm{C}$.

HOLOTYPE. SOUTH AFRICA, LIMPOPO PROVINCE: Bela-Bela, isolated from Cyrtogenius africus galleries on diseased Euphorbia ingens trees, August 2012, Van der Linde JA, holotype PREM 61238 dry culture on MEA, ex-holotype culture CMW38930 = CBS139747; paratype PREM 61240, ex-paratype culture CMW38940 = CBS140082.

Additional specimens examined: Bela-Bela, isolated from C. africus galleries on diseased E. ingens trees, August 2012, Van der Linde JA; CMW38929= CBS140081; CMW38932; CMW38931. 

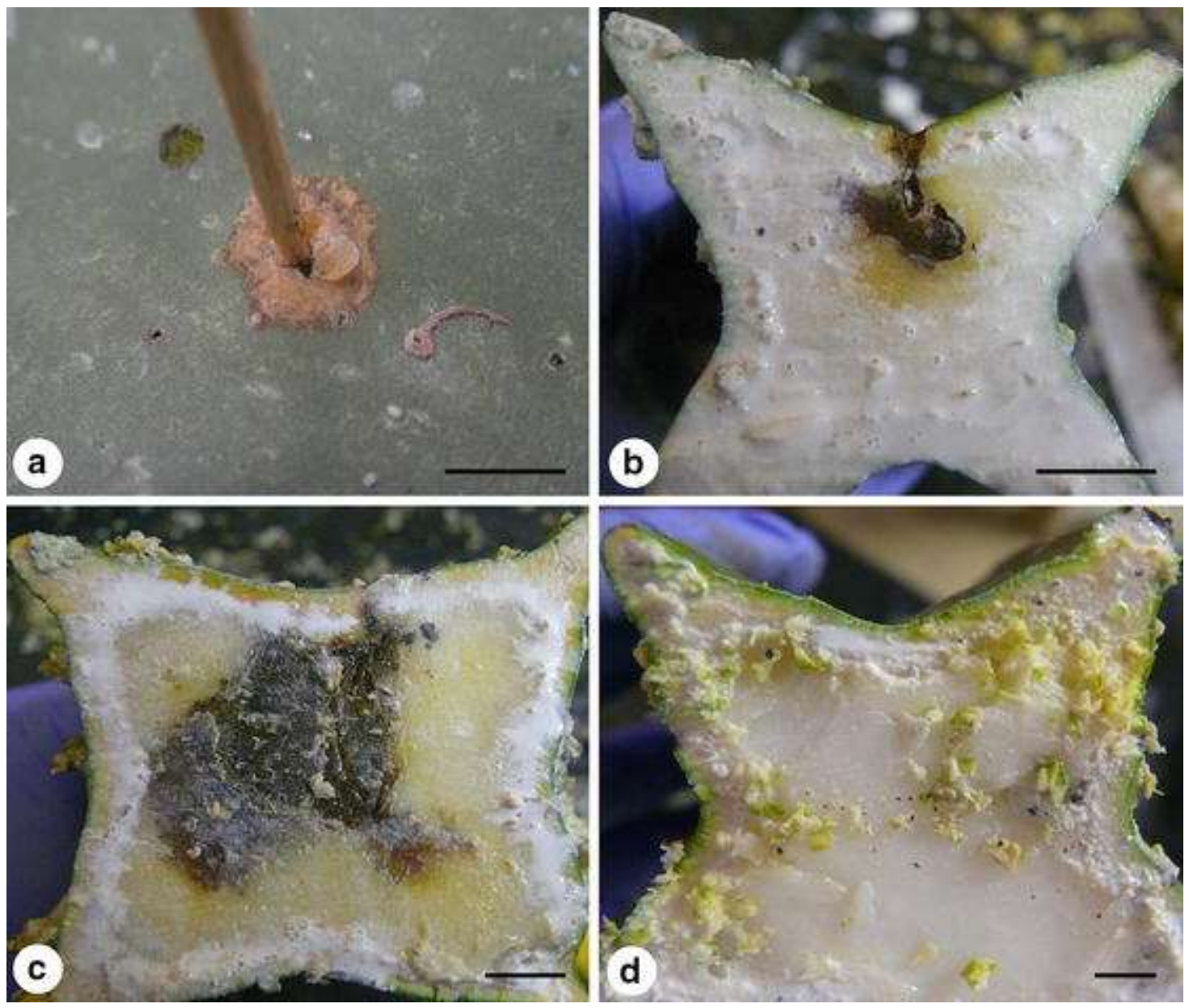

Fig. 5. Sections through $E$. ingens branches inoculated with $A$. volantis, $O$. thermarum and control inoculation. a Lesion produced by A. volantis (CMW42292) on the exterior of the succulent branches. b Internal rotting of succulent tissue produced by $O$. thermarum (CMW 38929). c Extensive rotting found in some cases, in this case produced by A. volantis (CMW41250). d Control inoculation showing no infection. Scale bars $\mathbf{a}-\mathbf{d}=10 \mathrm{~mm}$

\section{Pathogenicity}

Isolates of O. thermarum (CMW38940, CMW38930, CMW38929) and A. volantis

(CMW41238, CMW41250, CMW42292) produced internal rotting and external lesions at the

points of inoculation on healthy E. ingens trees. The external lesions at the points of inoculation surrounding the toothpicks were brown in color with dark brown rotted areas leading into the internal succulent tissue (Fig. 5a, b, c). Control inoculations produced no external lesions or internal rotting of the succulent branches (Fig. 5d). Both experiments produced similar results 
with significant differences in the length of the external tissue lesions, between the isolates extending from the points of inoculation $(\mathrm{F}$ test statistic $=13.250, \mathrm{df}=5, \mathrm{P}<0.001)$. There was no significant difference among depths ( $\mathrm{F}$ test statistic $=1.6907, \mathrm{df}=5, \mathrm{P}=0.1673$ ) and widths, between the isolates, $(\mathrm{F}$ test statistic $=1.0913, \mathrm{df}=5, \mathrm{P}=0.3854$ ) of the internal lesions (Fig. 6). Both species produced lesions that were significantly larger (Values from the Bonferroni procedure were all significant with $\mathrm{P}<0.05)$ than those of the controls. The two fungi used in the inoculations were consistently re-isolated and identified based on morphology, while no growth was produced from isolations from the control inoculations.

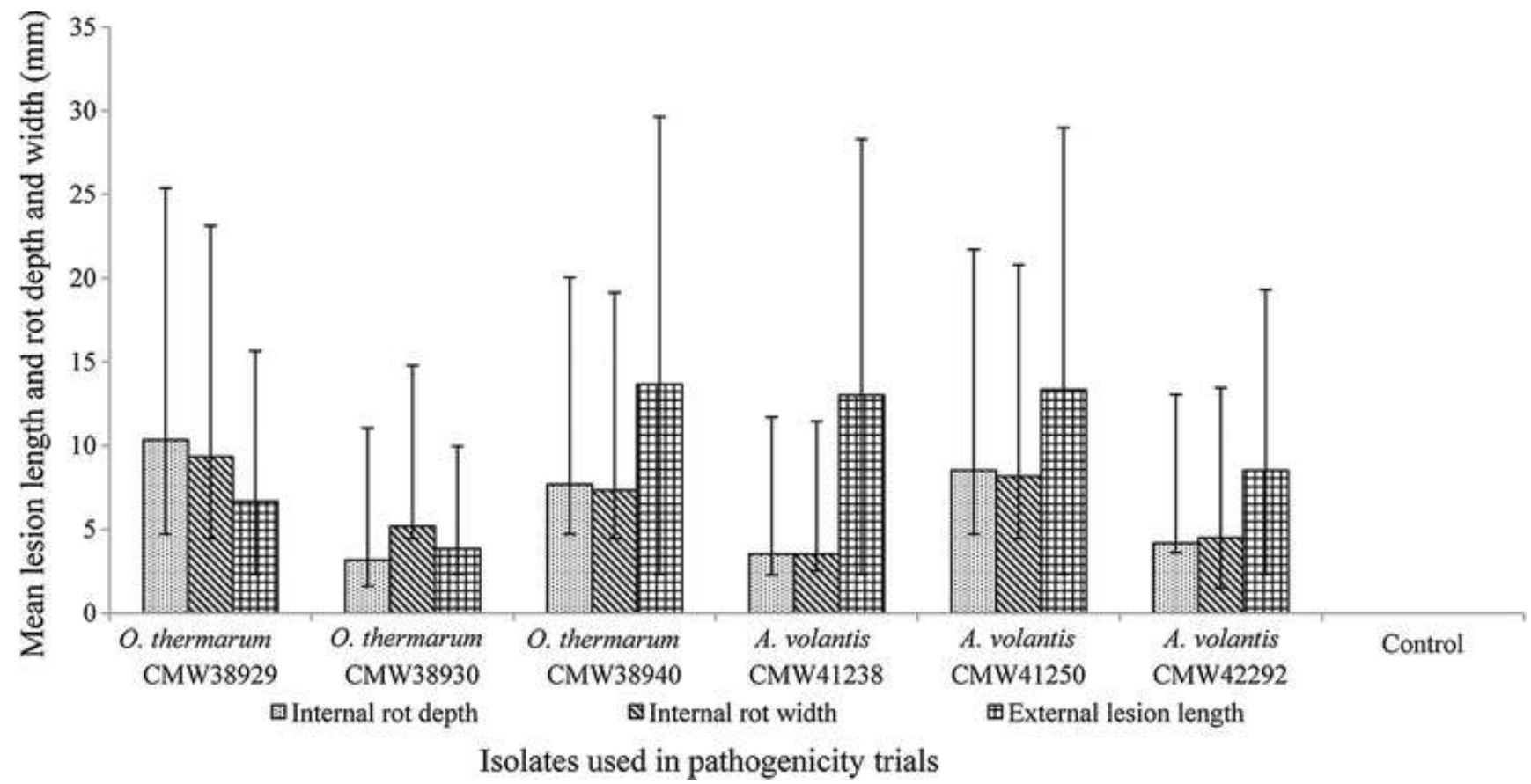

Fig. 6. Mean external lesion and internal rotting depth and width measurements obtained in inoculations of E. ingens branches with O. thermarum (CMW38929, CMW38930, CMW38940) and A. volantis (CMW41238, CMW41250, CMW42292). Error bars indicate $95 \%$ confidence limits for each isolate

\section{Discussion}

Fungi in the Ophiostomatales were identified from dying E. ingens trees at all sites investigated in this study. Previously, fungi in the Microascales were identified from dying $E$. 
ingens trees infested by Cossonus species in the Limpopo Province (Roux et al. 2009, Van der Linde et al. 2011b), but these fungi were not found here. This is the first report of fungi in the Ophiostomatales from dying E. ingens trees in South Africa. A species in a novel genus and a new Ophiostoma species were identified and described from the fungi isolated from the galleries of the ambrosia beetle $C$. africus infesting dying E. ingens trees.

The newly described genus, Aureovirgo, can be distinguished from other genera in the Ophiostomatales based on DNA sequence data and distinct morphological features. Aureovirgo is phylogenetically most closely related to Graphilbum H.P. Upadhyay \& W.B. Kendr. and species in the Sporothrix lignivora complex. It can, however, be distinguished from those genera based on its conidiophore morphology, as well as its conidia and ascospores. Aureovirgo has a leptographium-like asexual state as opposed to the sporothrix-like state in S. lignivora and pesotum-and hyalorhinocladiella-like states in Graphilbum (De Beer and Wingfield 2013). The ascospores are the most distinctive feature of Aureovirgo. Graphilbum species have rod-shaped ascospores with ossiform sheaths (De Beer and Wingfield 2013), while those of Aureovirgo are uniquely allantoid with ellipsoidal sheaths. A single species of Aureovirgo was identified in this study and described as $A$. volantis sp. nov.

A new species in the genus Ophiostoma Syd. \& P. Syd was identified and described as Ophiostoma thermarum sp. nov. Ophiostoma thermarum grouped peripheral to the Sporothrix schenckii-Ophiostoma stenoceras complex (De Beer et al. 2003), a group of fungi known to be associated with soil, hardwoods, Protea infructescences and mites (De Beer et al. 2003; Roets et al. 2008). Phylogenetic analyses revealed $O$. thermarum to be closely related to $O$. bragantinum Pfenning \& Oberw., described in Brazil from soil samples (Pfenning and Oberwinkler 1993). Ophiostoma bragantinum has shorter conidiophores (20 to $40 \mu \mathrm{m})$ and different conidial morphology (guttuliform or fusiform) compared to O. thermarum (Pfenning and Oberwinkler 1993). 
Previous studies on dying Euphorbia trees in South Africa identified two ophiostomatalean fungi from these trees, namely Knoxdaviesia serotectus (J.A. van der Linde, Jol. Roux) Z.W. de Beer \& M.J. Wingf. (on E. ingens) and K. ubusi (J.A. van der Linde, Jol. Roux) Z.W. de Beer \& M.J. Wingf. (on E. tetragona Haw.) (Van der Linde et al. 2011b). These species reside in the Microascales and were associated with rotting branches and a weevil in the genus Cossonus. Neither of these species were obtained from C. africus tunnels in diseased $E$. ingens trees in the current study. The weevil Cossonus infests only succulent parts of diseased E. ingens branches which is very different from C. africus, an ambrosia beetle that infests the woody xylem of diseased trees. The absence of Knoxdaviesia spp. in this study is thus not surprising.

Aureovirgo volantis and $O$. thermarum both produced external lesions and internal rotting in the inoculated E. ingens branches in the pathogenicity tests. Previously Van der Linde et al. (2011b) inoculated healthy E. ingens branches with two Knoxdaviesia species, which produced results similar to those found in the present study. Relatively small lesions and areas of internal rot were found associated with fungal inoculations in both studies although the results were variable (possibly due to genetic variation of $E$. ingens in their natural environment). This is in contrast to inoculations with Lasiodiplodia spp., also isolated from diseased E. ingens and capable of producing larger lesions (Van der Linde et al. 2011a). The results of the present study failed to show that either of the two ophiostomatalean fungi are primary pathogens. However, in the case of mass infestations, they could possibly contribute to tree death.

This study expands the base of knowledge regarding the diversity of ophiostomatalean fungi that occur in diseased $E$. ingens trees. It is now known that that this group of fungi occurs on diseased E. ingens trees across South Africa (where E. ingens populations occur). It was surprising that only two fungal species were obtained from the tunnels of C. africus. Interestingly, A. volantis and $O$. thermarum were never isolated from the same tunnel. Many 
ambrosia beetles carry more than one fungal partner and these fungi are often isolated together (Carrillo et al. 2014, Kostovcik et al. 2015). The association of ophiostomatalean fungi with $C$. africus and $E$. ingens die-offs deserves further study including additional collections from trees and beetles at different times of the year. Mass inoculations may also be sued to simulate the effect of fungi on trees after of mass attacks of host beetles. 


\section{References}

Batra LR (1967) Ambrosia fungi: A taxonomic revision, and nutritional studies of some species. Mycologia 59:976-1017

Beaver RA (1989) Insect-fungus relationships in the bark and ambrosia beetles. In: Wilding N, Collins NM, Hammond PM, Webber JF (eds) Insect-fungus interactions. Academic Press, London, pp 121-143

Carrillo D, Duncan RE, Ploetz JN, Campbell AF, Ploetz RC, Peña JE (2014) Lateral transfer of a phytopathogenic symbiont among native and exotic ambrosia beetles. Plant Pathol 63:54-62

De Beer ZW, Duong TA, Barnes I, Wingfield BD, Wingfield MJ (2014) Redefining Ceratocystis and allied genera. Stud Mycol 79:187-219

De Beer ZW, Harrington TC, Vismer HF, Wingfield BD, Wingfield MJ (2003) Phylogeny of the Ophiostoma stenoceras-Sporothrix schenckii complex. Mycologia 95:434-441

De Beer ZW, Seifert KA, Wingfield MJ (2013) The ophiostomatoid fungi: their dual position in the Sordariomycetes. In: Seifert KA, De Beer ZW, Wingfield MJ (eds) The Ophiostomatoid fungi: expanding frontiers. CBS Biodiversity Series 12, Utrecht, pp 1-19

De Beer ZW, Wingfield MJ (2013) Emerging lineages in the Ophiostomatales. In: Seifert KA, De Beer ZW, Wingfield MJ (eds) The Ophiostomatoid fungi: expanding frontiers. CBS Biodiversity Series 12, Utrecht, pp 21-46

Dowding P (1984) The evolution of insect-fungus relationships in the primary invasion of forest timber. In: Anderson JM, Raynor ADM, Walton DWH (eds) Invertebrate-microbial interactions. Cambridge University Press, New York, pp 133-153

Felsenstein J (1985) Confidence limits on phylogenies: an approach using the bootstrap. Evolution 39:783-791 
Fraedrich SW, Harrington TC, Rabaglia RJ et al (2008) A fungal symbiont of the redbay ambrosia beetle causes a lethal wilt in redbay and other Lauraceae in the southeastern United States. Plant Dis 92:215-224

Glass NL, Donaldson GC (1995) Development of primer sets designed for use with the PCR to amplify conserved genes from filamentous Ascomycetes. Appl Environ Microbiol 61:13231330

Harrington TC (2005) Ecology and evolution of mycophagous bark beetles and their fungal partners. In: Vega FE, Blackwell M (eds) Insect-fungal associations. Oxford University Press, New York, pp 257-291

Harrington TC, Fraedrich SW, Aghayeva DN (2008) Raffaelea lauricola, a new ambrosia beetle symbiont and pathogen on the Lauraceae. Mycotaxon 104:399-404

Hausner G, Reid J, Klassen GR (1993) On the subdivision of Ceratocystis s.l., based on partial ribosomal DNA sequences. Can J Botany 71:52-63

Huelsenbeck JP, Ronquist F (2001) MrBayes: Bayesian inference of phylogenetic trees. Bioinformatics 17:754-755

Hulcr J, Dunn RR (2011) The sudden emergence of pathogenicity in insect-fungus symbiosis threatens naive forest ecosystems. P R Soc B 278:2866-2873

Kamata N, Esaki K, Kato K, Igeta Y, Wada K (2002) Potential impact of global warming on deciduous oak dieback caused by ambrosia fungus Raffaelea sp. carried by ambrosia beetle Platypus quercivorus (Coleoptera: Platypodidae) in Japan. B Entomol Res 92:119-126

Katoh K, Misawa K, Kuma KI, Miyata T (2002) MAFFT: a novel method for rapid sequence alignment based on fast Fourier transform. Nucleic Acids Res 30:3059-3066 
Kostovcik M, Bateman CC, Kolarik M, Stelinski LL, Jordal BH, Hulcr J (2015) The ambrosia symbiosis is specific in some species and promiscuous in others: evidence from community pyrosequencing. ISME J 9:126-138

Kubono T, Ito S (2002) Raffaelea quercivora sp. nov. associated with mass mortality of Japanese oak, and the ambrosia beetle (Platypus quercivorus). Mycoscience 43:255-260

Malan R (2006) Aspects of population biology and ecology of Euphorbia ingens on the Mokopane game breeding centre in the Limpopo province of South Africa. Tech Nature Conservation, Department of Nature Conservation, Tshwane University of Technology Malloch D, Blackwell M (1993) Dispersal biology of the ophiostomatoid fungi. In: Wingfield MJ, Seifert KA, Webber JF (eds) Ceratocystis and Ophiostoma. The American Phytopathological Society Press, St. Paul, pp 195-206

Mrázková M, Černý K, Tomšovský M, Strnadová V (2011) Phytophthora plurivora T. Jung \& T.I. Burgess and other Phytophthora species causing important diseases of ericaceous plants in the Czech Republic. Plant Protec Sci 47:13-19

O'Donnell K, Cigelnik E (1997) Two divergent intragenomic rDNA ITS2 types within a monophyletic lineage of the fungus Fusarium are nonorthologous. Mol Phylogenet Evol 7:103116

Paine TD, Raffa KF, Harrington TC (1997) Interactions among scolytid bark beetles, their associated fungi, and live host conifers. Annu Rev Entomol 42:179-206

Pfenning L, Oberwinkler F (1993) Ophiostoma bragantinum n. sp., a possible teleomorph of Sporothrix inflata, found in Brazil. Mycotaxon 46:381-385

Ploetz RC, Hulcr J, Wingfield MJ, De Beer ZW (2013) Destructive tree diseases associated with ambrosia and bark beetles: Black swan events in tree pathology? Plant Dis 97:856-872 
Posada D (2008) jModelTest: phylogenetic model averaging. Mol Biol Evol 25:1253-1256

Ranger CM, Schultz PB, Frank SD, Chong JH, Reding ME (2015) Non-native ambrosia beetles as opportunistic exploiters of living but weakened trees. Plos one 10:1-21.

doi:10.1371/journal.pone.0131496

Réblová M, Gams W, Seifert KA (2011) Monilochaetes and allied genera of the Glomerellales, and a reconsideration of families in the Microascales. Stud Mycol 68:163-191

Roets F, de Beer ZW, Wingfield MJ, Crous PW, Dreyer LL (2008) Ophiostoma gemellus and Sporothrix variecibatus from mites infesting Protea infructescences in South Africa. Mycologia 100:496-510

Roux J, Malan R, Howitt M, Six D, Wingfield MJ (2008) Discovery of new fungi associated with the decline and death of Euphorbia ingens in the Limpopo province of South Africa. S Afr J Bot 74:377-378

Shapiro SS, Wilk MB (1965) Analysis of variance test for normality (complete samples). Biometrika 52:591-611

Six DL (2012) Ecological and evolutionary determinants of bark beetle-fungus symbioses. Insects 3:339-366

Spatafora JW, Blackwell M (1994) The polyphyletic origins of ophiostomatoid fungi. Mycol Res 98:1-9

Swofford DL (2002) PAUP* 4.0b10: phylogenetic analysis using parsimony (*and other methods). Sunderland, Massachusetts: Sinauer Associates

Tamura K, Dudley J, Nei M, Kumar S (2007) MEGA4: molecular evolutionary genetics analysis (MEGA) Version 4.0. Mol Biol Evol 8:1596-1599 
Van der Linde JA, Six DL, Wingfield MJ, Roux J (2011a) Lasiodiplodia species associated with dying Euphorbia ingens in South Africa. South Forests 73:165-173

Van der Linde JA, Six DL, Wingfield MJ, Roux J (2011b) New species of Gondwanamyces from dying Euphorbia trees in South Africa. Mycologia 104:574-584

Vilgalys R, Hester M (1990) Rapid genetic identification and mapping of enzymatically amplified Ribosomal DNA from several Cryptococcus species. J Bacteriol 172:4238-4246

White TJ, Bruns T, Lee S, Taylor J (1990) Amplification and direct sequencing of fungal ribosomal RNA genes for phylogenetics. In: Innis MA, Gelfand DH, Sninsky JJ, White TJ (eds) PCR protocols: a sequencing guide to methods and applications. Academic Press, San Diego, pp $315-322$

Wingfield MJ, Seifert KA, Webber J (1993) Ceratocystis and Ophiostoma: taxonomy, ecology and pathogenicity. The American Phytopathological Society Press, St. Paul

Wood SL (1982) The bark and ambrosia beetles of North and Central America (Coleoptera: Scolytidae), a taxonomic monograph. Great Basin Naturalist Memoirs 6

Zipfel RD, De Beer ZW, Jacobs K, Wingfield BD, Wingfield MJ (2006) Multi-gene phylogenies define Ceratocystiopsis and Grosmannia distinct from Ophiostoma. Stud Mycol $55: 75-97$ 